tions available, urine sensitivity reports, and communication with staff via the switchboard. We wished to establish the true extent of this dissatisfaction and to examine other areas where remedial action could lead to an improved service. The simplest approach was to circulate a questionnaire via the Family Practitioner Committee (now the FHSA) to all GPs in the area.

The questionnaire included questions that explored the general level of satisfaction with the service provided and satisfaction with the range of investigations, the timeliness of reports, report format, contact with laboratory staff-medical, technical and clerical - and educational activities. Respondents did not have to reveal their identity, although many chose to do so, and were given the opportunity to expand their views

Questionnaires were sent to each of 410 GPs in Norfolk of which 167 replied, a response rate of just over $40 \%$. Commercial experience would anticipate a response rate to a questionnaire of $15-20 \%$. The general level of satisfaction was reassuring. Particular areas of concern such as switchboard response and access to medical and laboratory staff were less of a widespread problem than we had thought, and seemed to indicate irritation rather than dissatisfaction. Other comments have allowed us to address a number of issues. A more appropriate range of urinary antibiotics has been incorporated into our reporting protocol. Normal values/ranges have been added to reports to facilitate interpretation of results. We are looking at the demand for increased educational contact. Some issues require further consultation and have important cost implications.

Individual complaints can create the impression that the service provided is far from satisfactory. It is important to obtain objective evidence of users' opinions, so that areas of improvement can be addressed. Staff morale can also be adversely affected by individual complaints. We all found this exercise both useful and rewarding. So, we believe, did our users.

We thank all the general practitioners who participated in the survey for their cooperation.

$$
\begin{array}{r}
\text { PMB WHITE } \\
\text { H WILLIAMS } \\
\text { J RICHARDS } \\
\text { Public Health Laboratory Service } \\
\text { Bowthorpe Road } \\
\text { Norwich, NR2 } 3 T Y
\end{array}
$$

1 Pedler SJ, Bint AJ. Survey of users' attitude to their local microbiology laboratory. J Clin Pathol 1991;44:6-9.

\section{Accreditation of clinical pathology laboratories in the United Kingdom: The story so far}

In 1988 an ad hoc committee of the Royal College of Pathologists was set up to consider how an accreditation scheme for the assessment of NHS and private laboratories in the United Kingdom might be developed. The impetus for such a scheme was derived from dicussions in Winnipeg following a meeting of the International Liaison Committee of Presidents, at which senior pathologists from both the College and the Association of Clinical Pathologists met with their American counterparts.

In 1989 a grant was obtained from the Trent Regional Health Authority to set up a pilot scheme in South Yorkshire, and Dr John Lilleyman was asked by the Committee to establish both the documentation and the methods by which such a pilot scheme could be conducted.

Subsequent development has led to an expansion of the Steering Group to include laboratory and other professionals from the ACP, ACB and IMLS, Independent Health Care Association and NHS management with observers from the Department of Health Scottish Health Department, the North of Ireland Health and Social Services Department and the Kings Fund. By this time the White Paper on health services had been published, giving an added impetus to the idea of medical audit, with the provision of finance for the development of such schemes.

In 1990 a phase 2 study was conducted in four regions during which more than 50 departments were inspected. The lessons learned from the two schemes has led to a continuing revision of the documentation together with the compilation of lists of potential inspectors, and a detailed itemisation of all clinical pathology laboratories in the United Kingdom. In the near future the prototype inspection for the permanen Accreditation Scheme will take place in Scotland and elsewhere.

It was quickly realised that much usefu information could be accumulated in the daylong laboratory inspection by having both a consultant pathologist and a senior medical laboratory scientific officer as a combined inspection team in each speciality, and this will probably become the pattern for the future.

Before the visit a manual, Guidelines for accreditation - the standards to achieve, is sen to the institution to be visited, together with request to complete an application form giving details of the department. Each inspecto has a manual with a checklist for each discipline based on a "tick box" format, covering all aspects of quality assessment, organisation and administration, personnel, facilities and equipment, policies and procedures and education.

Meetings are held not only with the consultant pathologists but also with members of the junior medical and technical staff, and with the hospital manager, and elected clinical and general practitioner representatives.

The pilot studies so far carried out have shown that $55-65 \%$ of laboratories would be accredited; $10 \%$ would fail, and the remainder have remedial deficiencies.

Recently a project manager (Mrs C Blair) has been appointed and an office set up in Sheffield while regional coordinators have been appointed to each region to assist the visitation process. In the near future a permanent Independent Accreditation Board will be created with a variable shareholding distributed between the Royal College of Pathologists and the Associations of Clinical Pathologists and Clinical Biochemists, the Institute of Medical Laboratory Sciences and NHS management. It is hoped to recrui other "users" to the Board, while "observers" from health departments in England, Wales, Scotland and Northern Ireland are likely to be invited to attend meetings.

An independent chairman with voting rights but without a shareholding will be appointed. The Board will be advised with respect to the granting of accreditation or otherwise by advisory panels in each discipline, in which it is hoped the specialist societies and the NEQUAS panels will be well represented.

In the absence of any untoward happenings it is hoped that the scheme will be launched live in late 1991, with visitations being scheduled initially on a three to four year cycle, accreditation being continued in the intervening years by the completion of a questionnaire.

GW PENNINGTON Chairman, Steering Group on Laboratory Accreditation, The Royal College of Pathologists, 2 Carlton House Terrace London, SW 1 Y $5 A F$

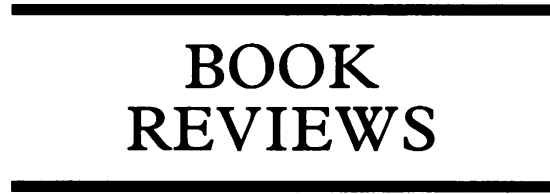

All titles reviewed here are available from the BMJ Bookshop, PO Box 295, London WC1H 9TE. Prices include postage in the United Kingdom and for members of the British Forces Overseas, but overseas customers should add $£ 2$ per item for postage and packing. Payment can be made by cheque in sterling drawn on a United Kingdom bank, or by credit card (Mastercard, Visa or American Express) stating card number, expiratory date, and your full name.

Year Book of Pathology and Clinical Pathology. 1990. Ed KM Brinkhouse. (Pp 385; £44.) Wolfe Publishing Ltd. 1990. ISBN 0-8151-1245-90.

This 43rd annual volume continues the series which is based on a selection of articles by a group of editors from 850 journals, with an abstract by the author and comments by an editor. This year the dominant theme is the application of new techniques in genetics, particularly the polymerase chain reaction, to general pathology and clinical pathology with its subspecialties. The general pathology papers as a group make fascinating reading and have been written so as to make the subject comprehensible to the non-geneticist. Apart from molecular genetics, there are review articles on the pulmonary-renal syndrome, classification of small cell carcinoma of the lung, and on fine needle aspiration of tumours. The book concludes with a list of selective new reviews, particularly in haematology. While in no way replacing a computed literature search of a specific topic, this year book gives an excellent overall review of pathology as we enter the last decade of the 20 th century.

NK SHINTON

Clinical Immunology. A Practical Approach. Ed HC Gooi, H Chapel. The Practical Approach Series. (Pp 263; 22.50.) Oxford University Press. 1990 ISBN 0-19-963086-0.

This is a simple short book illustrating the spectrum of techniques involved in clinical immunology. There are nine chapters covering antibody and cellular deficiencies, neutrophil function tests and complement measurements, cellular and immunochemical investigations in lymphoid malignancy, autoantibodies and allergy. A strength of the book is the inclusion of appendices on how to 